\title{
Yeast chromium and digestible lysine levels in finishing pigs subjected to high ambient temperatures
}

\author{
Alexandre Pereira dos Santos $^{1}$ (D) Charles Kiefer ${ }^{1 *}$ (iD) Karina Márcia Ribeiro de Souza Nascimento ${ }^{1}$ (i) \\ Anderson Corassa ${ }^{2}$ (D) Jéssica Lira da Silva ${ }^{1}$ Taynah Vieira Aguiar Farias ${ }^{1}$ (D) \\ Stephan Alexandre da Silva Alencar $^{1}$ (i) Denise de Santana Lima ${ }^{1}$ (D)
}

\begin{abstract}
${ }^{1}$ Programa de Pós-graduação em Ciência Animal, Universidade Federal de Mato Grosso do Sul (UFMS), 79070-900, Campo Grande, MS, Brasil. E-mail: charles.kiefer@ufms.br. "Corresponding author.

${ }^{2}$ Universidade Federal de Mato Grosso (UFMT), Sinop, MT, Brasil.

ABSTRACT: This study evaluated the effects of chromium yeast and digestible lysine levels on the performance and carcass characteristics of finishing pigs. Sixty-four barrows with an initial weight of $72.77 \pm 7.20 \mathrm{~kg}$ and final weight of $119.44 \pm 9.47 \mathrm{~kg}$ were used, distributed in a $2 \times 2$ factorial scheme, with two levels of chromium yeast (Cr0: 0 ppb and Cr800: 800 ppb) and two levels of digestible lysine (L0: recommended level and $L+10 \%$ : 10\%). The recorded air temperature of $30.9 \pm 3.7^{\circ} \mathrm{C}$ during the experimental period was considered as heat stress. Performance variables were not influenced $(P>0.05)$; however, $L+10 \%$ showed an increase $(P<0.05)$ in daily digestible lysine intake. Carcass characteristics of the animals were not influenced $(P>0.05)$ by the chromium or digestible lysine levels. Supplementation with 800 ppb of yeast chromium and a 10\% increase in the level of digestible lysine, isolated or associated, did not improve the performance and carcass characteristics of finishing pigs, subjected to high ambient temperatures.
\end{abstract}

Key words: additive, amino acids, nutrition, minerals.

Níveis de cromo levedura e lisina digestível para suínos em terminação sob temperaturas ambientais elevadas

RESUMO: Realizou-se este estudo com o objetivo de avaliar os efeitos de níveis de cromo levedura e lisina digestivel, desempenho e características de carcaça de suínos em terminação. Foram utilizados 64 machos castrados com peso inicial de 72,77 \pm 7,20 kg e final de $119,44 \pm 9,47 \mathrm{~kg}$, distribuidos em esquema fatorial $2 \times 2$, sendo dois níveis (Cr0: 0 ppb e Cr800: 800 ppb) e dois níveis de lisina digestivel (L0: nivel recomendado e $L+10 \%: 10 \%$ ). A temperatura do ar registrada de $30,9 \pm 3,7{ }^{\circ} \mathrm{C}$ durante o periodo experimental foi considerada como de estresse por calor. As variáveis de desempenho não foram influenciadas $(P>0,05)$, contudo $L+10 \%$ aumentou $(P<0,05)$ o consumo de lisina digestivel diário. As características de carcaça dos animais não foram influenciadas $(P>0,05)$ pelos níveis de cromo levedura e lisina digestivel. A suplementação de 800 ppb de cromo levedura, e o aumento em 10\% do nível de lisina digestivel, isolados ou associados, não melhoram o desempenho e as características de carcaça de suínos em terminação submetidos a temperaturas ambientais elevadas. Palavras-chave: aditivos, aminoácidos, nutrição, minerais.

\section{INTRODUCTION}

Elevated environmental temperatures are one of the most common stressing agents in swine production systems, which mainly affect the finishing swine. The temperatures adversely affect behavior and hinder swine performance (KIEFER et al., 2010).

In pigs under stress, chromium supplementation in the swine diets improves the immunological status (WANG et al., 2007), minimizes the response to stress agents (LIU et al., 2017), and improves the performance and carcass traits (PARK et al., 2009; WANG et al., 2014). Chromium promotes protein synthesis in skeletal muscle by modulating the anabolic action of insulin (PECHOVA \& PAVLATA, 2007). The mTOR signaling pathway functions as a central regulator of cell metabolism (LAPLANTE \& SABATINI, 2009).

Growth factors such as insulin and GH activate mTOR complexes, which are essential for protein synthesis; other factors such as leucine and glutamine and the levels of essential amino acids in the diet are also critical for the activation (KIM et al., 2013). Diets containing insufficient levels of amino acids could inhibitor hinder mTOR activation; and consequently, the protein synthesis (ESCOBAR et 
al., 2006; SURYAWAN et al., 2008; LAPLANTE \& SABATINI, 2009).

Results from the studies on chromiumrelated research, regardless of its level or source used in the experimental diets, could possibly be influenced by environmental temperatures. Therefore, this study evaluated the effects of dietary supplementation of chromium yeast and digestible lysine, in terms of the ideal protein concept on the performance and carcass traits of finishing swine, grown under high environmental temperatures.

\section{MATERIALS AND METHODS}

Sixty-four barrows, classified as of high potential for gain according to ROSTAGNO et al. (2017), with initial weight of $72.77 \pm 7.20 \mathrm{~kg}$ and final weight of $119.44 \pm 9.47 \mathrm{~kg}$, were used. Pigs were distributed in a $2 \times 2$ factorial design comprising of two chromium levels ( $\mathrm{Cr} 0: 0 \mathrm{ppb}$ and Cr800: $800 \mathrm{ppb}$ ) and two digestible lysine levels (L0: recommended level and $\mathrm{L}+10 \%: 10 \%$ ), totaling four treatments, with eight replicates and two pigs per replicate. The initial weight of the pigs was used as the blocking factor, and the pen was considered as the experimental unit.

Pigs were allotted in a masonry shed with ceramic hoof tiles and fenced sides. Pigpens $(1.15 \times$ $2.85 \mathrm{~m}$ ) were of solid concrete floor with a "shallow pool" at one end of the pen, equipped with feeders and nipple water dispensers. Thermal variables inside the shed were recorded daily at $08 \mathrm{~h}$ and $16 \mathrm{~h}$ throughout the experimental period using a portable digital thermometer (model ITWTG2000). The variables recorded were dry bulb temperature, wetbulb temperature, black globe, and relative humidity. The thermal variables were used to determine the black globe humidity index, according to the equation proposed by BUFFINGTON et al. (1981).

The experimental diets (Tables 1 and 2) were formulated using corn and soybean meal, minerals, and vitamins to meet the nutritional requirements of the pigs (ROSTAGNO et al., 2017). Kaolin was replaced with the necessary quantity of chromium yeast, to correspond to $800 \mathrm{ppb}$ of chromium. Digestible lysine levels were through supplementation of L-Lysine, DLMethionine, L-Threonine and L-Tryptophan to maintain the ideal protein concept established by ROSTAGNO et al. (2017). There was no need to supplement the other amino acids, because the diet already satisfied the minimal ratio proposed in the ideal protein concept.
The pigs had ad libitum access to feed and water throughout the experimental period. Feed leftovers on the floor were collected daily, weighed weekly, and then added to weights of the feed leftovers inside the feeder at the end of every experimental phase, to determine the daily feed intake. The intakes of digestible lysine, crude protein, and metabolizable energy were estimated based on the daily feed intake and according to the estimated concentration of nutrients in the diets. Pigs were weighed using an electronic weighing machine at the beginning of the trial and at the end of each experimental phase (phase I: $70-100 \mathrm{~kg}$; phase II: $100-120 \mathrm{~kg}$ ), to determine the daily weight gain. The feed: gain ratio was calculated based on the feed intake and weight gain.

For harvesting, animals were desensitized by electronarcosis, then bled, scalded, dehaired, and eviscerated. At the end of the slaughter line, the carcasses were weighed to obtain the hot carcass weight and then split into two halves through a longitudinal cut at the line corresponding to the vertebral column. Backfat thickness, longissimus dorsi muscle depth, and lean meat percentage were determined at the $\mathrm{P} 2$ measuring point of the left half of the carcass using a Hennessy Grading System GP4/BP4 electronic typification pistol.

The data were analyzed, considering the levels of chromium and digestible lysine as fixed effects and the block as a random effect using the PROC GLIMMIX procedure with SAS 9.1 statistical analysis program (SAS, 2004). The response criteria were evaluated for the primary effects and the potential interactions between chromium and digestible lysine. The significance level was set at $5 \%$.

\section{RESULTS AND DISCUSSION}

Mean environmental temperature $(30.9 \pm$ $\left.3.7{ }^{\circ} \mathrm{C}\right)$, globe temperature $\left(31.1 \pm 3.6^{\circ} \mathrm{C}\right)$, relative humidity $(59.3 \pm 20.4 \%)$, and black globe humidity index $(80.2 \pm 3.9)$ allow the characterization of the thermal environment as heat stress for finishing pigs. Temperatures above the upper critical temperature of $22{ }^{\circ} \mathrm{C}$ (RENAUDEAU et al., 2011) and the black globe humidity index above 82.7 are established as conditions of heat stress for finishing pigs (KIEFER et al., 2010).

The levels of chromium and digestible lysine did not influence $(\mathrm{P}>0.05)$ the performance of pigs (Table 3 ); however, there was an increase $(\mathrm{P}<0.05)$ in the daily estimated digestible lysine intake. The increased amino acid supply in $\mathrm{L}+10 \%$ diets led to a higher intake in Phase I $(\mathrm{P}<0.05)$, Phase 
Table 1 - Centesimal and nutritional composition of experimental diets from 70 to $100 \mathrm{~kg}$.

\begin{tabular}{|c|c|c|c|c|}
\hline \multirow[t]{2}{*}{ Ingredients } & \multicolumn{4}{|c|}{  } \\
\hline & CrOLO & $\mathrm{Cr} 0 \mathrm{~L}+10 \%$ & Cr800L0 & $\mathrm{Cr} 800 \mathrm{~L}+10 \%$ \\
\hline Corn & 79.815 & 79.815 & 79.815 & 79.815 \\
\hline Soybean meal, $46.5 \%$ & 15.693 & 15.693 & 15.693 & 15.693 \\
\hline Soy oil & 1.700 & 1.700 & 1.700 & 1.700 \\
\hline Dicalcium phosphate & 0.863 & 0.863 & 0.863 & 0.863 \\
\hline Limestone & 0.594 & 0.594 & 0.594 & 0.594 \\
\hline Salt & 0.368 & 0.368 & 0.368 & 0.368 \\
\hline L-Lysine $\mathrm{HCl}, 77.5 \%$ & 0.339 & 0.444 & 0.339 & 0.444 \\
\hline DL-Methionine, $99.5 \%$ & 0.071 & 0.120 & 0.071 & 0.120 \\
\hline L-Treonine, $96.8 \%$ & 0.076 & 0.132 & 0.076 & 0.132 \\
\hline L-Tryptophan, $99.0 \%$ & 0.032 & 0.048 & 0.032 & 0.048 \\
\hline Premix vitamin and mineral ${ }^{1}$ & 0.150 & 0.150 & 0.150 & 0.150 \\
\hline Inert (kaolin) & 0.300 & 0.074 & 0.250 & 0.024 \\
\hline Yeast chromium $^{2}$ & 0.000 & 0.000 & 0.050 & 0.050 \\
\hline \multicolumn{5}{|c|}{ 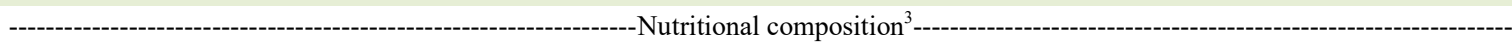 } \\
\hline Crude protein, $\%$ & 14.145 & 14.285 & 14.145 & 14.285 \\
\hline Net energy, Mcal kg ${ }^{-1}$ & 2.570 & 2.570 & 2.570 & 2.570 \\
\hline Calcium, \% & 0.497 & 0.497 & 0.497 & 0.497 \\
\hline Disponible phosphorus, $\%$ & 0.242 & 0.242 & 0.242 & 0.242 \\
\hline Sodium, \% & 0.165 & 0.165 & 0.165 & 0.165 \\
\hline Digestible lysine, $\%$ & 0.805 & 0.886 & 0.805 & 0.886 \\
\hline Digestible meth + cyst, \% & 0.483 & 0.532 & 0.483 & 0.532 \\
\hline Digestible treonine, $\%$ & 0.523 & 0.576 & 0.523 & 0.576 \\
\hline Digestible tryptophan, \% & 0.161 & 0.177 & 0.161 & 0.177 \\
\hline Digestible valine, $\%$ & 0.563 & 0.563 & 0.563 & 0.563 \\
\hline
\end{tabular}

${ }^{1}$ Content per kilogram of product: vit. A: 1,250,000 UI, vit. D3: 250,000 UI, vit. E: 6,250 UI, vit. K3: 750 mg, vit. B1: 375 mg, vit. B2: 1,000 mg, vit. B6: $375 \mathrm{mg}$, vit. B12: 4,500 mg, pantothenic acid: 2,300 mg, folic acid: $125 \mathrm{mg}$, iron: $25 \mathrm{mg}$, copper: $3,750 \mathrm{mg}$, manganese: $12.5 \mathrm{~g}$, zinc: $31.25 \mathrm{~g}$, iodine: $250 \mathrm{mg}$, selenium: $75 \mathrm{mg}$, and excipient.

${ }^{2}$ Supplementation of $50 \mathrm{~g}$ of yeast chromium to obtain diets with $800 \mathrm{ppb}$ of yeast chromium.

${ }^{3}$ Values calculated based on the nutritional composition of raw materials (ROSTAGNO et al., 2017).

II $(\mathrm{P}<0.05)$, and for the total experimental period $(\mathrm{P}<0.05)$. This is an expected response, because there was no difference between the daily feed intake and the increase in amino acid supply, following the ideal protein concept.

In this study, none of the performance variables were affected by chromium supplementation; however, the possible effects of elevated environmental temperatures, during the experimental period, needs to be considered. Finishing pigs are extremely sensitive to high environmental temperatures (KIEFER et al., 2010), and for the entire experimental period, temperatures were much higher than the upper critical limit of $22{ }^{\circ} \mathrm{C}$, as recommended for finishing swine (RENAUDEAU et al., 2011), and maximum temperatures of up to $39^{\circ} \mathrm{C}$ were frequently observed.
The primary effects that are often observed and measured in pigs under heat stress conditions are decreased feed intake and modifications in carcass composition (ROSS et al., 2015; MARTÍNEZ-MIRÓ et al., 2016; CAMPOS et al., 2017). A decrease in feed intake is influences weight gain and the feed:gain ratio (KIEFER et al., 2010). However, both feed intake and weight gain of the pigs did not decrease, in response to the elevated temperatures recorded during the experimental period. Therefore, they were classified as high-performance pigs, according to the Brazilian requirement tables (ROSTAGNO et al., 2017). This could be attributed to the adaptability of the lineage used in this study to heat stress conditions (ROSS et al., 2015).

There was no interaction $(\mathrm{P}>0.05)$ between the levels of chromium and digestible lysine and 
Table 2 - Centesimal and nutritional composition of experimental diets from 100 to $120 \mathrm{~kg}$.

\begin{tabular}{|c|c|c|c|c|}
\hline \multirow[t]{2}{*}{ Ingredients } & \multicolumn{4}{|c|}{ 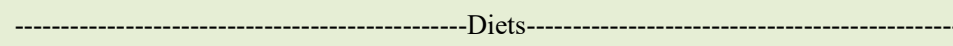 } \\
\hline & CrOLO & $\mathrm{Cr} 0 \mathrm{~L}+10 \%$ & Cr800L0 & $\mathrm{Cr} 800 \mathrm{~L}+10 \%$ \\
\hline Corn & 85.271 & 85.271 & 85.271 & 85.271 \\
\hline Soybean meal, $46.5 \%$ & 11.152 & 11.152 & 11.152 & 11.152 \\
\hline Soy oil & 1.000 & 1.000 & 1.000 & 1.000 \\
\hline Dicalcium phosphate & 0.758 & 0.758 & 0.758 & 0.758 \\
\hline Limestone & 0.546 & 0.546 & 0.546 & 0.546 \\
\hline Salt & 0.349 & 0.349 & 0.349 & 0.349 \\
\hline L-Lysine $\mathrm{HCl}, 77.5 \%$ & 0.336 & 0.426 & 0.336 & 0.426 \\
\hline DL-Methionine, $99.5 \%$ & 0.042 & 0.085 & 0.042 & 0.085 \\
\hline L-Treonine, $96.8 \%$ & 0.062 & 0.110 & 0.062 & 0.110 \\
\hline L-Tryptophan, $99.0 \%$ & 0.033 & 0.047 & 0.033 & 0.047 \\
\hline Premix vitamin and mineral $^{1}$ & 0.150 & 0.150 & 0.150 & 0.150 \\
\hline Inert (kaolin) & 0.300 & 0.104 & 0.250 & 0.054 \\
\hline Yeast chromium $^{2}$ & 0.000 & 0.000 & 0.050 & 0.050 \\
\hline \multicolumn{5}{|c|}{ - } \\
\hline Crude protein, $\%$ & 12.270 & 12.397 & 12.270 & 12.397 \\
\hline Net energy, Mcal kg ${ }^{-1}$ & 2.570 & 2.570 & 2.570 & 2.570 \\
\hline Calcium, \% & 0.444 & 0.444 & 0.444 & 0.444 \\
\hline Disponible phosphorus, $\%$ & 0.216 & 0.216 & 0.216 & 0.216 \\
\hline Sodium, \% & 0.158 & 0.158 & 0.158 & 0.158 \\
\hline Digestible lysine, $\%$ & 0.697 & 0.767 & 0.697 & 0.767 \\
\hline Digestible meth + cyst, $\%$ & 0.418 & 0.460 & 0.418 & 0.460 \\
\hline Digestible treonine, $\%$ & 0.453 & 0.499 & 0.453 & 0.499 \\
\hline Digestible tryptophan, \% & 0.139 & 0.153 & 0.139 & 0.153 \\
\hline Digestible valine, $\%$ & 0.492 & 0.492 & 0.492 & 0.492 \\
\hline
\end{tabular}

${ }^{1}$ Content per kilogram of product: vit. A: 1,250,000 UI, vit. D3: 250,000 UI, vit. E: 6,250 UI, vit. K3: 750 mg, vit. B1: 375 mg, vit. B2: 1,000 mg, vit. B6: $375 \mathrm{mg}$, vit. B12: 4,500 mg, pantothenic acid: 2,300 mg, folic acid: $125 \mathrm{mg}$, iron: $25 \mathrm{mg}$, copper: $3,750 \mathrm{mg}$, manganese: $12.5 \mathrm{~g}$, zinc: $31.25 \mathrm{~g}$, iodine: $250 \mathrm{mg}$, selenium: $75 \mathrm{mg}$, and excipient.

${ }^{2}$ Supplementation of $50 \mathrm{~g}$ of yeast chromium to obtain diets with $800 \mathrm{ppb}$ of yeast chromium.

${ }^{3}$ Values calculated based on the nutritional composition of raw materials (ROSTAGNO et al., 2017).

the carcass traits (Table 4). The levels of chromium and digestible lysine did not influence $(\mathrm{P}>0.05)$ the carcass traits of the pigs.

Pigs under heat stress conditions showed decreased protein deposition and increased fat tissue deposition (ROSS et al., 2015), which was also observed in this study. There was a tendency for both an increase in backfat thickness $(\mathrm{P}=0.102)$ and a decrease in lean meat percentage $(\mathrm{P}=0.109)$. In addition, heat stress may increase insulin sensitivity in pigs (FERNANDEZ et al., 2015). Therefore, the increase in the backfat thickness of pigs receiving diets with a $10 \%$ increase in amino acid, compared to that fed recommended dietary digestible lysine levels, could be attributed to the deamination and utilization of amino acids in excess as energy, resulting in deposition as lipids in the adipose tissue (VAN MILGEN \& DOURMAD, 2015).

The most important function of chromium as a modulator of protein synthesis in pigs under heat stress is probably because of its influence on the mTOR mechanism and on the expression of heat shock proteins (HSPs) (GANESAN et al., 2017). The mTOR mechanism is essential for the synthesis of HSPs under heat stress conditions. The activation of factors inducing the synthesis of HSPs under heat stress conditions is dependent on the mTOR signaling pathway. In cells that have an inactivated mTOR pathway, HSPs are not expressed in response to the heat stress. In others, heat stress activates the 
Table 3 - Levels of yeast chromium and digestible lysine on the performance of finishing pigs.

\begin{tabular}{|c|c|c|c|c|c|c|c|c|}
\hline \multirow[t]{2}{*}{ Variables } & \multirow{2}{*}{$\begin{array}{l}\mathrm{Cr} 0 \\
\mathrm{~L} 0\end{array}$} & \multirow{2}{*}{$\begin{array}{c}\mathrm{Cr} 0 \\
\mathrm{~L}+10 \%\end{array}$} & \multirow{2}{*}{$\begin{array}{c}\mathrm{Cr} 800 \\
\mathrm{~L} 0\end{array}$} & \multirow{2}{*}{$\begin{array}{l}\text { Cr800 } \\
\mathrm{L}+10 \%\end{array}$} & \multirow[t]{2}{*}{ SEM } & \multicolumn{3}{|c|}{---------------P value--------------- } \\
\hline & & & & & & $\mathrm{Cr}$ & $\mathrm{L}$ & $\mathrm{Cr} \times \mathrm{L}$ \\
\hline Initial weight & 72.72 & 72.66 & 72.84 & 72.85 & 2.687 & 0.802 & 0.968 & 0.955 \\
\hline Final weight phase I & 98.25 & 97.98 & 97.34 & 97.96 & 2.963 & 0.721 & 0.894 & 0.732 \\
\hline Final weight phase II & 120.22 & 119.71 & 118.32 & 120.50 & 3.053 & 0.746 & 0.629 & 0.434 \\
\hline \multicolumn{9}{|c|}{  } \\
\hline DFI, $\mathrm{kg}$ & 3.26 & 3.33 & 3.20 & 3.32 & 0.127 & 0.864 & 0.611 & 0.884 \\
\hline DWG, kg & 1.02 & 1.01 & 0.98 & 1.00 & 0.028 & 0.546 & 0.844 & 0.684 \\
\hline $\mathrm{FC}$ & 3.19 & 3.28 & 3.26 & 3.32 & 0.075 & 0.603 & 0.487 & 0.853 \\
\hline DDLI, g & 26.28 & 29.51 & 25.80 & 29.46 & 1.056 & 0.861 & 0.031 & 0.889 \\
\hline DNEI, Mcal & 8.39 & 8.58 & 8.24 & 8.57 & 0.328 & 0.867 & 0.582 & 0.885 \\
\hline \multicolumn{9}{|c|}{ 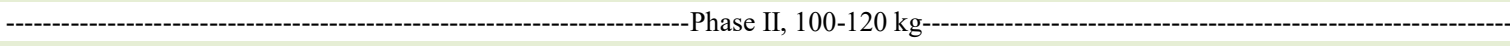 } \\
\hline DFI, kg & 3.25 & 3.19 & 3.18 & 3.39 & 0.099 & 0.628 & 0.572 & 0.341 \\
\hline DWG, kg & 1.04 & 1.03 & 1.00 & 1.07 & 0.030 & 0.913 & 0.447 & 0.297 \\
\hline $\mathrm{FC}$ & 3.12 & 3.11 & 3.18 & 3.18 & 0.098 & 0.624 & 0.988 & 0.962 \\
\hline DDLI, $\mathrm{g}$ & 22.63 & 24.45 & 22.16 & 26.05 & 0.729 & 0.599 & 0.011 & 0.334 \\
\hline DNEI, Mcal & 8.35 & 8.22 & 8.17 & 8.75 & 0.254 & 0.627 & 0.536 & 0.341 \\
\hline \multicolumn{9}{|c|}{ 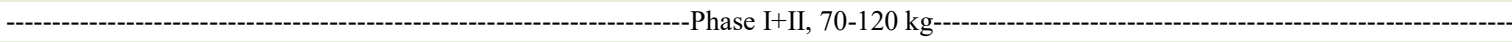 } \\
\hline DFI, $\mathrm{kg}$ & 3.25 & 3.26 & 3.19 & 3.36 & 0.103 & 0.902 & 0.558 & 0.582 \\
\hline DWG, $\mathrm{kg}$ & 1.03 & 1.02 & 0.99 & 1.04 & 0.022 & 0.646 & 0.542 & 0.360 \\
\hline $\mathrm{FC}$ & 3.16 & 3.20 & 3.22 & 3.25 & 0.071 & 0.510 & 0.685 & 0.938 \\
\hline DDLI, $\mathrm{g}$ & 24.61 & 27.21 & 24.14 & 27.90 & 0.829 & 0.928 & 0.013 & 0.626 \\
\hline DNEI, Mcal & 8.37 & 8.42 & 8.21 & 8.65 & 0.268 & 0.927 & 0.528 & 0.610 \\
\hline
\end{tabular}

Cr: chromium, L: lysine, DFI: daily feed intake, DWG: daily weight gain, FC: feed conversion, DDLI: daily digestible lysine intake, DNEI: daily net energy intake.

mTOR pathway for the expression of HSPs; however, the downstream factors that are crucial for protein synthesis via mTOR are blocked.

Therefore, under heat stress conditions, there is a potential for chromium to promote protein synthesis via the mTOR-signaling pathway. However, there is a probability of decrease in the resulting anabolism, because the amino acids from the diets are redirected for synthesizing HSPs for acclimatizing the animal to the stress resulting from high temperatures (CHOU et al., 2012).

Table 4 - Levels of yeast chromium and digestible lysine on the carcass characteristics of finishing pigs.

\begin{tabular}{|c|c|c|c|c|c|c|c|c|}
\hline Variables & $\mathrm{Cr} 0$ & $\mathrm{Cr} 0$ & Cr800 & $\mathrm{Cr} 800$ & SEM & \multicolumn{3}{|c|}{ 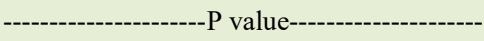 } \\
\hline & L0 & $\mathrm{L}+10 \%$ & L0 & $\mathrm{L}+10 \%$ & & $\mathrm{Cr}$ & $\mathrm{L}$ & Crx L \\
\hline $\mathrm{HCW}, \mathrm{kg}$ & 89.30 & 90.07 & 89.21 & 89.88 & 2.474 & 0.932 & 0.646 & 0.977 \\
\hline $\mathrm{CY}, \%$ & 74.82 & 76.02 & 75.69 & 75.28 & 0.548 & 0.878 & 0.328 & 0.067 \\
\hline $\mathrm{BT}, \mathrm{mm}$ & 17.28 & 19.59 & 17.03 & 19.30 & 1.071 & 0.843 & 0.102 & 0.988 \\
\hline $\mathrm{LD}, \mathrm{mm}$ & 65.95 & 65.95 & 64.27 & 64.67 & 1.095 & 0.355 & 0.899 & 0.898 \\
\hline LM, \% & 55.03 & 53.02 & 54.82 & 53.11 & 0.919 & 0.960 & 0.109 & 0.894 \\
\hline
\end{tabular}

Cr: chromium, L: lysine, HCW: hot carcass weight, CY: carcass yield, BT: backfat thickness, LD: loin depth, LM: lean meat.

Ciência Rural, v.52, n.3, 2022. 


\section{CONCLUSION}

Supplementation with $800 \mathrm{ppb}$ of chromium yeast and an increase of $10 \%$ in digestible lysine levels, either in isolation or in concurrence, does not improve the performance and carcass traits in finishing pigs under elevated environmental temperatures.

\section{ACKNOWLEDGEMENTS}

The authors thank the Fundação de Apoio ao Desenvolvimento do Ensino, Ciência e Tecnologia do Estado de Mato Grosso do Sul (FUNDECT), Conselho Nacional de Desenvolvimento Científico e Tecnológico (CNPq), Universidade Federal de Mato Grosso do Sul (UFMS), and Coordenação de Aperfeiçoamento de Pessoal de Nível Superior - Brasil (CAPES; Finance Code 001) for the financial support in the execution of the research project.

\section{BIOETHICS AND BIOSSECURITY COMMITTEE APPROVAL}

The project was approved by the ethics committee in the use of animals, protocol number 625/2014 - Universidade Federal de Mato Grosso do Sul (UFMS).

\section{DECLARATION OF CONFLICT OF INTEREST}

The authors declare no conflict of interest. The funding sponsors had no role in the design of the study; in the collection, analyses, or interpretation of data; in the writing of the manuscript, and in the decision to publish the results.

\section{AUTHORS' CONTRIBUTIONS}

All authors contributed equally for the conception and writing of the manuscript. All authors critically revised the manuscript and approved of the final version.

\section{REFERENCES}

BUFFINGTON, D. E. et al. Black globe humidity index (BGHI) as comfort equation for dairy cows. Transaction of the American Society of Agricultural Engineers, v.24, p.711-714, 1981. Available from: <https://elibrary.asabe. org/abstract.asp?aid=34325>. Accessed: Feb. 05, 2019. doi: $10.13031 / 2013.34325$.

CAMPOS, P. H. R. F. et al. Physiological responses of growing pigs to high ambient temperature and/or inflammatory challenges. Revista Brasileira de Zootecnia, v.46, p.537-544, 2017. Available from: $<$ https://www.scielo.br/pdf/rbz/v46n6/1806-9290rbz-46-06-0537.pdf>. Accessed: Feb. 05, 2019. doi: 10.1590/ s1806-92902017000600009.

CHOU, S. D. et al. mTOR is essential for the proteotoxic stress response, HSF1 activation and heat shock protein synthesis. PLoS One, v.7, e39679, 2012. Available from: <https://journals.plos.org/ plosone/article?id=10.1371/journal.pone.0039679>. Accessed: Feb. 05, 2019. doi: 10.1371/journal.pone.0039679.

ESCOBAR, J. et al. Regulation of cardiac and skeletal muscle protein synthesis by individual branched-chain amino acids in neonatal pigs. American Journal of Physiology. Endocrinology and Metabolism, v.290, p.612-621, 2006. Available from: $<$ https:// journals.physiology.org/doi/full/10.1152/ajpendo.00402.2005>. Accessed: Feb. 05, 2019. doi: 10.1152/ajpendo.00402.2005.

FERNANDEZ, M. V. S. et al. Heat stress increases insulin sensitivity in pigs. Physiological Reports, v.3, e12478, 2015. Available from: <https://physoc.onlinelibrary.wiley.com/doi/ pdf/10.14814/phy2.12478>. Accessed: Feb. 05, 2019. doi: 10.14814 phy2.12478.

GANESAN, S. et al. Acute heat stress activated inflammatory signaling in porcine oxidative skeletal muscle. Physiological Reports, v.5, e13397, 2017. Available from: <https://physoc. onlinelibrary.wiley.com/doi/pdf/10.14814/phy2.13397>. Accessed: Feb. 05, 2019. doi: 10.14814/phy2.13397.

KIEFER, C. et al. Response of finishing swine maintained in different thermal environments. Revista Brasileira de Saúde e Produção Animal, v.11, p.496-504, 2010. Available from: $<$ https:// portalseer.ufba.br/index.php/rbspa/article/view/40250/22420>. Accessed: Feb. 05, 2019.

KIM, S. G. et al. Nutrient regulation of the mTOR complex 1 signaling pathway. Molecules and Cells, v.35, p.463-473, 2013. Available from: <https://www.ncbi.nlm.nih.gov/pmc/articles/ PMC3887879/>. Accessed: Feb. 05, 2019. doi: 10.1007/s10059013-0138-2.

LAPLANTE, M.; SABATINI, D. M. mTOR signaling at a glance. Journal of Cell Science, v.122, p.3589-3594, 2009. Available from: $\quad<$ https://jcs.biologists.org/content/joces/122/20/3589.full. pdf>. Accessed: Feb. 05, 2019. doi: 10.1242/jcs.051011.

LIU, F. et al. Effects of chromium supplementation on physiology, feed intake, and insulin related metabolism in growing pigs subjected to heat stress. Translational Animal Science, v.1, p.116-125, 2017. Available from: <https://academic.oup.com/tas/ article/1/1/116/5466094?login=true $>$. Accessed: Feb. 05, 2019. doi: $10.2527 / \operatorname{tas} 2017.0014$.

MARTÍNEZ-MIRÓ, S. et al. Causes, consequences and biomarkers of stress in swine: an update. BMC Veterinary Research, v.12, p.1-9, 2016. Available from: <https://link.springer.com/ article/10.1186/s12917-016-0791-8>. Accessed: Feb. 05. 2019. doi: 10.1186/s12917-016-0791-8.

PARK, J. K. et al. Effects of different sources of dietary chromium on growth, blood profiles and carcass traits in growing-finishing pigs. Asian-Australasian Journal of Animal Sciences, v.22, p.1547-1554, 2009. Available from: <https://www.ajas.info/ upload/pdf/22-200.pdf>. Accessed: Oct. 20. 2020. doi: 10.5713/ ajas.2009.80633.

PECHOVA, A.; PAVLATA, L. Chromium as an essential nutrient: a review. Veterinarni Medicina, v.52, p.1-18, 2007. Available from: $<$ http://citeseerx.ist.psu.edu/viewdoc/download?doi=10.1.1. 597.6963\&rep $=$ rep1\&type $=$ pdf $>$. Accessed: Feb. 01. 2021.

RENAUDEAU, D. et al. A meta-analysis of the effects of high ambient temperature on growth performance of growing-finishing 
pigs. Journal of Animal Science, v.89, p.2220-2230, 2011. Available from: <https://hal.inrae.fr/hal-02646507/document>. Accessed: Feb. 05. 2019. doi: 10.2527/jas.2010-3329.

ROSS, J. W. et al. Physiological consequences of heat stress in pigs. Animal Production Science, v.55, p.1381-1390, 2015. Available from: <https://www.researchgate.net/profile/Lance Baumgard/ publication/283787786_Physiological_consequences_of_heat stress_in_pigs/links/5bc0ad0092851c88fd659e67/Physiologicalconsequences-of-heat-stress-in-pigs.pdf $>$. Accessed: Feb. 05, 2019. doi: 10.1071/AN15267.

ROSTAGNO, H. S. et al. Brazilian tables for poultry and swine: Food composition and nutritional requirements. Viçosa-MG, 4th ed., 2017. 488p.

SAS - Statistical Analysis System. Version 9.1.3. Cary: SAS Institute Inc., 2004.

SURYAWAN, A. et al. Leucine stimulates protein synthesis in skeletal muscle of neonatal pigs by enhancing mTORC1 activation. American Journal of Physiology. Endocrinology and
Metabolism, v.295, p.868-875, 2008. Available from: <https:// journals.physiology.org/doi/full/10.1152/ajpendo.90314.2008>. Accessed: Feb. 05, 2019. doi: 10.1152/ajpendo.90314.2008.

VAN MILGEN, J.; DOURMAD, J. Y. Concept and application of ideal protein for pigs. Journal of Animal Science and Biotechnology, v.6, p.1-11, 2015. Available from: <https://link. springer.com/article/10.1186/s40104-015-0016-1>. Accessed: Feb. 05, 2019. doi: 10.1186/s40104-015-0016-1.

WANG, M. Q. et al. Effects of chromium nanocomposite supplementation on blood metabolites, endocrine parameters and immune traits in finishing pigs. Animal Feed Science and Technology, v.139, p.69-80, 2007. Available from: $<$ https://doi. org/10.1016/j.anifeedsci.2006.12.004>. Accessed: Oct. 20. 2020. doi: 10.1016/j.anifeedsci.2006.12.004.

WANG, M. Q. Effects of chromium-loaded chitosan nanoparticles on growth, carcass characteristics, pork quality, and lipid metabolism in finishing pigs. Livestock Science, v.161, p.123-129, 2014. Available from: <https://doi.org/10.1016/j.livsci.2013.12.029>. Accessed: Oct. 20. 2020. doi: 10.1016/j.livsci.2013.12.029. 